\title{
Ultrastructural Study of the Neuromuscular Junctions of Extensor Digitorum Longus Muscle (M. extensor digitorum longus) of the Mice
}

\author{
Estudio Ultraestructural de las Uniones Neuromusculares del Músculo \\ Extensor Largo de los Dedos (M. extensor digitorum longus) del Ratón
}

*Sueli N. Boaro \& ** Raul A. Fragoso Neto

$\overline{\text { BOARO, S. N.; FRAGOSO NETO, R. A. Ultrastructural study of the neuromuscular junctions of extensor digitorum longus muscle }}$ (M. extensor digitorum longus) of the mice. Int. J. Morphol., 27(3):927-932, 2009.

SUMMARY: The neuromuscular junction of the extensor digitorum longus muscle of fingers was analyzed in 21 young (three months) and old (from six to 25 months) mice, from both genders. Morphologic changes were found throughout the mouse life, being more frequent and visible with aging. According with the data described in the literature consulted and the observations taken in this research, it becomes clear that a continuous process of morphological remodeling occurs in all neuromuscular ultrastructural junctions of the extensor digitorum longus muscle of fingers, during the life of the animal. Theses changes are characterized by figures of myelin in the cytoplasm of Schwann cells, pleomorphic and multivesiclar bodies, mitochondrias with morphologically altered crests in the axon terminal and degenerated junction folders. Coated vesicles are common in older animals and rare in young animals.

KEY WORDS: Neuromuscular junctions; Mice; Ultrastructure; Extensor digitorum longus muscle.

\section{INTRODUCTION}

Modern knowledge in neuromuscular junction structure began with Couteaux work (1947). Most findings by this author, presented after his observations of NMJs with Janus Green B, were later confirmed with the advent of histochemical studies (Couteaux \& Taxi, 1952; Coers, 1967), and at ultra-structural level (Palade, 1954; Robertson, 1954; Birks et al., 1960).

In the consulted literature, the general $\mathrm{NMJ}_{\mathrm{S}}$ charecteristics in mammals indicate that they are dynamic structures and undergo morphological remodeling processes (variation of depth of synaptic cleft, sprouting, retraction and degree of ramification of the terminal axon, density, length, layout and quantity of synaptic vesicles, etc.). Such aspects may vary according to the species and age of the animal, or yet, in different physiological situations, such as during the decrease of physical activity or total muscular immobility (Stebbins et al., 1985; Fahim \& Robbins, 1986).
There is considerable information about developing and mature NMJs, but the changes that occur with aging were not extensively studied yet and the results of researches available are not in total agreement (Townes-Anderson \& Raviola, 1978; Fahim \& Robbins, 1982; Cardasis, 1983; Wernig et al., 1984; Rosenheimer \& Smith, 1985; Cardasis \& La Fontaine, 1987; Soares et al., 1993). From about ten years ago to nowadays, a few researches tried to establish the morphological and functional differences that the NMJs undergo in rats according to their age, without using, nonetheless, mice, which are the objects of the present work (Jianjun et al., 2002; Deschenes \& Wilson, 2003; Apel et al., 2008).

This research had as objective to analyze the alterations present in neuromuscular junctions at ultrastructural level in extensor digitorum longus muscle of fingers of mice, during development until senility.

* Department of Physical Education of Faculdade de Ciências e Tecnologia, São Paulo State University “Júlio de Mesquita Filho" (UNESP), Presidente Prudente, SP - Brazil.

** Department of Physiotherapy of Faculdade de Ciências e Tecnologia, São Paulo State University "Júlio de Mesquita Filho" (UNESP),Presidente Prudente, SP - Brazil. 


\section{MATERIAL AND METHOD}

Twenty one Albino Swiss mice (Mus musculus), from both genders, out bred, given by the Departament of Microbiology and Immunology of Paulista State Univesity "Júlio de Mesquita Filho" - UNESP, Botucatu Campus, were maintained with solid and liquid diet ad libitum. The ages of these animals were $3,6,9,13,17,21$ and 25 months (3 animals per age). Those with 3 months of age were considered to be young and the ones with 6 months of age and on were considered to be old.

After the sacrifice of the animals, an incision of the skin and muscular fascia of the posterior region of the leg was carried out. After that, the cranial tibial muscle was removed. This way, the extensor digitorum longus muscle became apparent. This muscle as reduced and fixed in gluaraldehyde $2.5 \%$ by 24 hours, washed in phosphate buffer $(\mathrm{pH} 7.3)$ and then post-fixed in osmium tetroxide $1 \%$. After dehydratation in crescent concentrations of acetone the muscle was immersed in equal parts of araldite and acetone, for 24 hours at room temperature. The samples were then included in araldite, at $37^{\circ} \mathrm{C}$ for 1 hour and blocked in araldite, at $60^{\circ} \mathrm{C}$, for 48 hours. After trimming the material obtained, semi-fine cuts were carried out and inked with uranile acetate in alcohol $50 \%$. After selection of the regions with NMJs, 600 Å cuts were done, using a KLB ultratome III 8800 ultramicrotome. The material obtained was examined and photographed in a Philips EM 301 electronic microscope. The number of NMJs analyzed varied in function of the number of NMJs found at the transmission electronic microscope in each studied age.

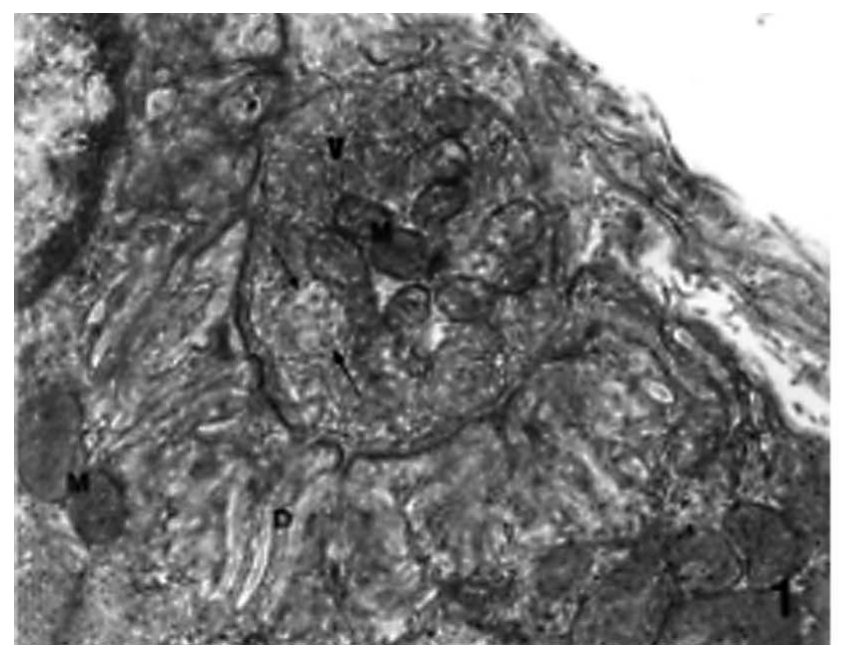

\section{RESULTS}

The NMJs ultrastructures from the extensor digitorum longus muscle were studied in the 21 mice. In all ages analyzed (3, 6, 9, 13, 17, 21 and 25 months) we found that the area of synaptic contact persisted in all NMJs of the extensor digitorum longus muscle. However, with aging of the mice (13 months), the areas of normal synaptic contact became sparse in some occasions. In these cases, the junctional folders were sparse and, when present, where short (Fig. 1).

In young animals ( 3 months), we noted the terminal axon with a large quantity of synaptic vesicles, some mitochondrias morphologically altered, showing loss of their crests, different from subsarcolemal mitochondrias that were preserved, junctional folders showing signs of morphological alterations that were preserved and kidnapping of synaptic vesicles (Fig. 2). In other occasions, we observed the terminal axon with coated vesicles and narrow and long junctional folders. Next to the NMJs, we noted an uncovered area, without contact with the correspondent terminal axon (Fig. 3). In other situations, we observed the axon with a large quantity of pratically homogen synaptic vesicles, degenerated mitochondrias, vacuoles and morphologically altered junctional folders. The basal membrane was thickened. It was also discontinued in all situations.

In animals with six months, the NMJs showed axonal mitochondrias with loss and breaking of crests. The synaptic vesicles were homogen and multivesiclar bodies were observed. In animals with 9 to 21 months, we noted the

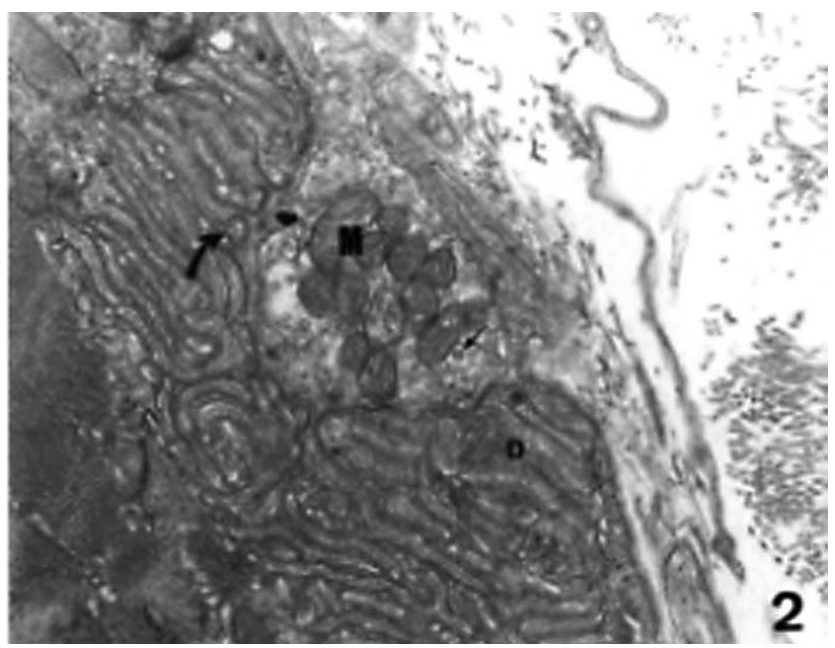

Figs. 1 and 2. Electromicrographies of NMJs of the extensor digitorum longus muscle of mice with three months. The terminal axon is found in large quantities in synaptic vesicles (V) scattered along all terminal axon and mitochondria (M) showing loss of its crests. The subsarcolemal mitochondria are preserved. Please, note a kidnap of synaptic vesicles (small arrows). Coated vesicle (small arrow - Fig.2) is present, synaptic vesicle kidnapping (short arrow - Fig.2) and places of the uncovered junctional folders. $47520 \mathrm{X}$ and $36300 \mathrm{X}$, respectively. 

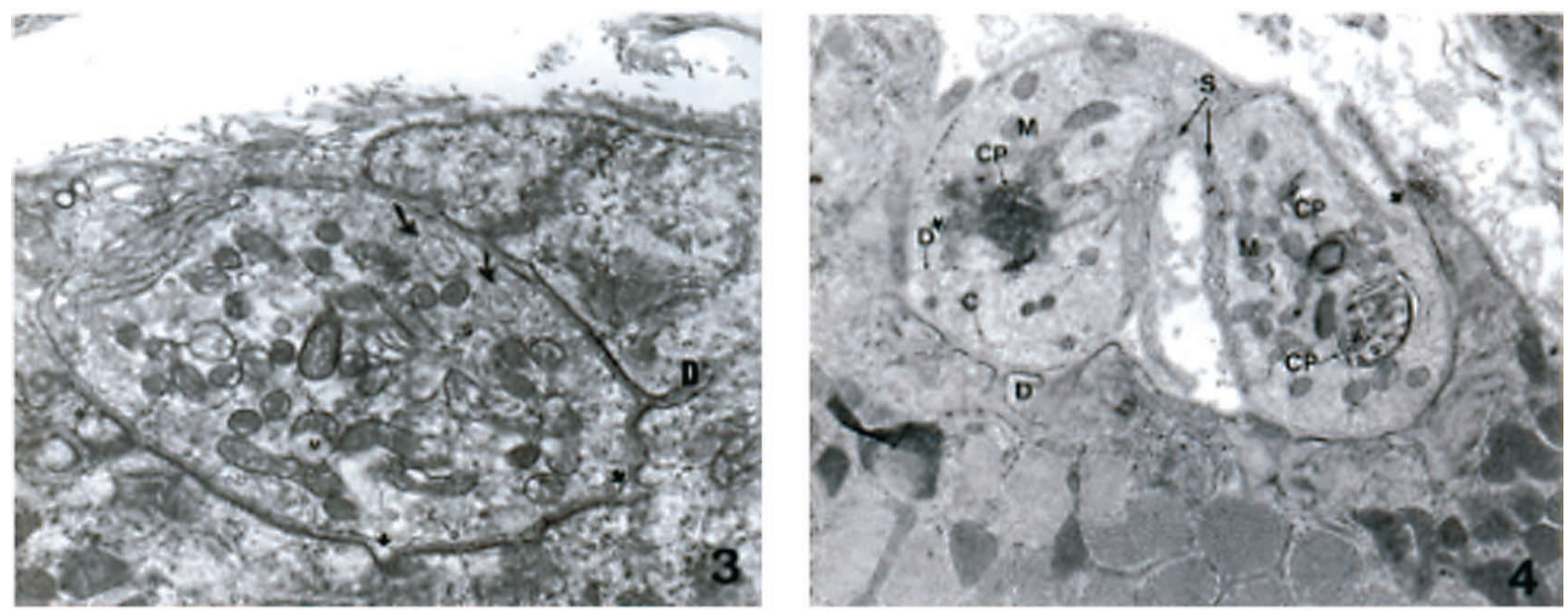

Fig. 3. Electromicrography of NMJ of the extensor digitorum longus muscle of mice with 13 months. The terminal axon shows large quantity of synaptic vesicles $(\mathrm{S})$ and coated $(\mathrm{C})$, degenerated mitochondria (M), discontinuity of basal membrane (small arrows) and multivesiclar bodies (curved arrows). Please, note the reduced number of junctional folders. $36300 \mathrm{X}$.

Fig. 4. Electromicrography of NMJ of the extensor digitorum longus muscle of mice with 21 months. The terminal axon shows few synaptic vesicles and large quantity of coated vesicles. Note the cytoplasm of Schwann cell (S) between two terminal axons, as well as dense core $\left(\mathrm{D}^{*}\right)$ vesicle, pleomorphic body $(\mathrm{CP})$ and morphologically mischaracterized mitochondria (M). Collagen fibrils at synaptic cleft (arrow) and degenerated junctional folders (D). $27720 \mathrm{X}$.
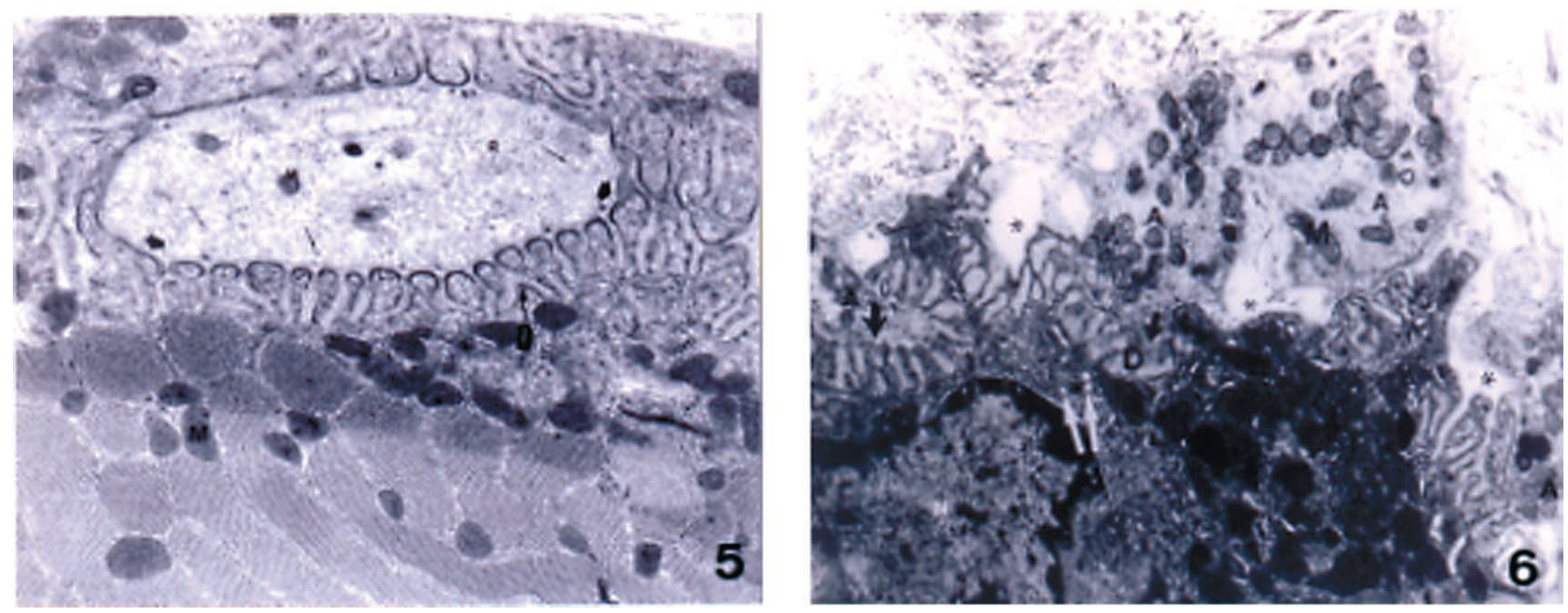

Fig. 5. Electromicrography of NMJ of the extensor digitorum longus muscle of mice with 21 months. There is a terminal axon with large quantity of coated vesicles (small arrows) and mitochondrias (M) morphologically deprived of characteristics. There is also discontinuity of axonal membrane (short arrows). Note the smooth endoplasmatic reticulum (R) and branched junctional folders (D). $27720 \mathrm{X}$.

Fig. 6. Electromicrography of NMJ of the extensor digitorum longus muscle of mice with 25 months. Note the presence of terminal axons associated to widened and branched junctional folders (D), many of which degenerated. In all terminal axons the synaptic vesicles are rare, the central axons show degenerated mitochondria $(\mathrm{M})$, there are unoccupied synaptic clefts $(*)$ and, in some parts of the terminal axon there is axonal membrane (arrows). In the junctional sarcoplasm, vacuoles are shown (white arrows). Note the nucleus of the muscle cell $(\mathrm{N}) .36300 \mathrm{X}$.

Schwann cell over the synapse. Its prolongations were continuous by projections of the basal membrane and involved all NMJs region. The synaptic vesicles were homogen and the junctional folders were widened and degenerated. The subsarcolemal mitochondria were globulated.
In some situations, in elder animals, we could take pictures of terminal axons with large quantities of homogen synaptic vesicles, degenerated vacuoles and mitochondria and with broken crests. We noted, still, preservation of basal membrane. The junctional folders were degenerated in animals with 17 months. In other animals of same age, it was possible 
to visualize, in the axon, the presence of myelin figures, multivesiclar bodies and very altered mitochondria.

Other important characteristic observed in the NMJs in elder animals were two terminal axons and citoplasmatic projections from the Schwann cell involving nervous terminals (Fig. 4). Normally, this involved animals with advanced age (21 months). We could visualize figures similar to the smooth endoplasmatic reticle in the axon of the NMJs that showed, still, small quantities of synaptic vesicles and pleomorphic bodies. Associated normally to this configuration, we visualized junctional folders completelly degenerated. In some elder animals, we found terminal axons showing many coated vesicles and a small number of tipical synaptic vesicles, as well as morphologically descha-racterized mitochondria. The basal membrante showed discontinuity. The junctional folders were narrow and long, and sometimes, branched (Fig. 5).

In animals with 25 months of age, the desorganization of NMJs was total (Fig. 6). The junctional folders were, in their majority, degenerated. Discontinuity in the basal membrane was present in all axons observed. The synaptic vesicles were rare. The axons showed a great number of degenerated mitochondria and the synaptic clefts were partially unocuppied. In the junctional sarcoplasm, vacuoles and mitochondria without apparent alterations were observed.

\section{DISCUSSION}

Mice are animals that show some advantages if one is studying the NMJs. These animals present normal motor activity through their whole lives. Besides that, their most common pathologies during senility are easily detected, which allows the researcher to exclude the animal from the work group (Fahim \& Robbins, 1982).

According to Fahim \& Robbins (1982) the degree of muscle activity in the animal affects the morphological changes in the NMJs, observed with aging. In the present study, all electromicrographies of NMJs in elder animals showed signs of morphologic alteration associated to modifications that, according to the literature, are related to aging.

The Schwann cell is fundamental to the integrity of the normal NMJs architecture. In degenerative processes, its function is relevant as was showed in many situations. Terminal axons totally isolated from junctional folders by cytoplasmic projections in Schwann cells, like the ones detected in nine axons in the present study, are cited in the literature (Cardasis \& Padykula, 1981; Fahim \& Robbins, 1982; Cardasis, 1983). Thus, Fahim \& Robbins (1982) and Cardasis (1983), suggest that this phenomenon would be associated to the degeneration and retraction of the terminal axon.

All axons involved by projections of Schwann cells showed deep alterations in form. In this study, the nervous terminations of elder animals didn't show dense core vesicles as related by Cardasis (1983) and Cardasis \& La Fontaine, although these authors didn't observed such structures in axons in state of degeneration.

A curious fact in this study was the constant presence, in axons, of multivesiclar bodies and mitochondria in different degenerative stages. In elder animals (21 and 25 months), the presence of vesicles sparse and in little quantity was constant. According to Smith and Rosenheimer (1982), there is a rise in the number of these structures in the NMJs in elder animals. However, these authors didn't explain what this rise could represent.

The presence of pleomorphic bodies according to Cardasis (1983) should represent accumulation of remnants of synaptic vesicles or mitochondria. According to the author, it is common the presence of these structures in axons of elder animals. In this study, it was found only one case, in a mouse with 21 months. There is no explanation, in the consulted literature, for the presence of multivesicular bodies in the interior of the terminal axon. Maybe these structures could represent early stages of the pleomorphic bodies observed inthe terminal axon of the NMJs in the extensor digitorum longus muscle in mice with 21 months.

Cardasis \& Padykula and Cardasis (1983) found a thickened basal membrane in NMJs in elder rats. This aspect was also observed in this work, in the same conditions. According to Gutmann \& Hanslíkóvá (1965), the NMJs in elder animals in process of degenerations suggest a decline in the number of muscular fibers in which the junctions are present. For these authors, the decrease in the number of muscular fibers might have been due to the loss of motor units.

According to the data presented here, and the observations carried out along this research, it seems clear that a continuous process of morphologic remodeling in all synapses of the extensor digitorum longus muscle is present during the whole life of the animal. The ultra-structural changes that occur in the NMJs become more apparent and frequent between 3 and 21 months of age in mice.

To Lexell (1997), the progressive degeneration of the peripheral nervous system in human skeletal muscle causes changes in muscles. However, it is not clear in the consulted literature if the degeneration of the NMJs causes loss of associated muscle fibers or vice-versa. 
BOARO, S. N. \& FRAGOSO NETO, R. A. Estudio ultraestructural de las uniones neuromusculares del músculo extensor largo de los dedos (M. extensor digitorum longus) del ratón. Int. J. Morphol., 27(3):927-932, 2009.

RESUMEN: La ultraestructura de las uniones mioneurales del músculo extensor largo de los dedos fue analizada en 21 ratones, jóvenes (tres meses) y viejos (de seis a 25 meses), de ambos sexos. Los cambios morfológicos fueron encontrados en toda la vida del ratón, siendo más frecuentes y visibles en el envejecimiento. Según los datos descritos en la literatura comsultada y las observaciones tomadas en esta investigación, se concluye que un proceso continuo de remodelación morfológica ocurre en todas las uniones mioneurales del músculo extensor largo de los dedos, durante la vida del animal. Tales cambios son caracterizados por figuras de mielina en el citoplasma de las células del neurilema, cuerpos pleomórficos y multivesiculares, mitocondrias con crestas morfologicamente cambiadas y pliegues de unión degeneradas. Las vesículas son comunes en animales más viejos y raras en animales jóvenes.

PALABRAS CLAVE: Uniones mioneurales; Ratón; Ultraestructura; M. extensor largo de los dedos.

\section{REFERENCES}

Apel, P. J.; Alton, T.; Northam, C.; Ma, J.; Callahan, M.; Sonntag, W. E. \& Li, Z. How age impairs the response of the neuromuscular junctions to nerve transection and repair: an experimental study in rats. J. Orthop. Res., 26:1-9, 2008.

Birks, R.; Huxley, H. E. \& Katz, B. The fine structure of the neuromuscular junction of the frog. J. Physiol., 150:1434, 1960 .

Cardasis, C. A. Ultrastructural evidence of continued reorganization of the aging (11-26 months) rat soleus neuromuscular junction. Anat. Rec., 207:399-415, 1983.

Cardasis, C. A. \& Padykula, H. A. Ultrastructural evidence indicating reorganization at the neuromuscular junction in the normal rat soleus muscle. Anat. Rec., 200:41-59, 1981.

Cardasis, C. A. \& La Fontaine, D. M. Aging rat neuromuscular junctions: a morphometric study of cholinesterase stained whole mounts and ultrastructure. Muscle Nerve, 10:200-13, 1987.

Coers, C. Structure and organization of myoneural junction. Int. Rev. Cytol., 22:239-67, 1967.

Couteaux, R. Contribution à l' etude da la synapse myoneurale. Rev. Can. Biol., 6:563-711, 1947.

Couteaux, R. \& Taxi, J. Recherches histochimiques sur la distribution desactivités cholinesterasiques au niveau de la synapse myoneurale. Arch. Anat. Microsc. Morphol. Exp., 41:352-92, 1952.

Deschenes, M. R. \& Wilson, M. H. Age-related differences in synaptic plasticity following muscle unloading. $J$. Neurobiol.,57(3):246-56, 2003.
Fahim, M. A. \& Robbins, N. Ultrastructural studies of young and old mouse neuromuscular junctions. J. Neurocytol., 11(4):641-56, 1982.

Fahim, M. A. \& Robbins, N. Remodeling of the neuromuscular junction after subtotal disuse. Brain Res., 383:383-56, 1986.

Gutmann, E. \& Hanslíkóvá, V. Age changes of motor endplates in muscle fibres of the rat. Age changes of motor endplates in muscle fibres of the rat. Gerontology, 11:12-24, 1965.

Jianjun, M. A.; Smith, B. P.; Smith, T. L. et al. Juvenile and adult rat neuromuscular junctions: density, distribution and morphology. Muscle Nerve, 26:804-9, 2002.

Lexell, J. Evidence for nervous system degeneration with advancing age. J. Nutr., 127:1011-3, 1997.

Palade, G. E. Electron microscope observations of interneuronal and neuromuscular synapses. Anat. Rec., 118:335-6, 1954.

Robertson, J. D. Electron microscope observations on a reptilian myoneural junction. Anat. Rec., 118:346, 1954.

Rosenheimer, J. L. \& Smith, D. O. Differencial changes in the end-plate architecture of funcionally diverse muscles during aging. J. Neurophysiol., 53:1567-81, 1985.

Smith, D. O. \& Rosenheimer, J. L. Decreased sprouting and degeneration of nerve terminals of active muscles in aged rats. J. Neurophysiol., 48:100-9, 1982.

Soares, J. C.; Ogata, T. \& Yamasaki, Y. Reorganization of neuromuscular junction in rat abdominal oblique muscle. International Symposium on Morphological Sciences, Barcelona, 1993. 
Stebbins, C. L.; Schultz, E.; Smith, R. T. \& Smith, E. L. Effects of chronic exercise during aging on muscle and end-plate morphology in rats. Am. Physiol. Soc., 4:4551, 1985 .

Townes-Anderson, E. \& Raviola, G. Degeneration and regeneration of autonomic nerve endings in the anterior part of rhesus monkey ciliary muscle. J. Neurocytol., 7:583-600, 1978.

Wernig, A.; Carmody, J. J.; Anzil, A. P., et al. Persistence of nerve sprouting with features of synapse remodeling in soleus muscles of adult mice. Neuroscience, 11:241-53, 1984.
Correspondence to:

Prof. Dr. Sueli N. Boaro

Department of Physical Education

Faculdade de Ciências e Tecnologia

São Paulo State University

"Júlio de Mesquita Filho" (UNESP)

P.O. Box n. 467 - CEP 19060-900

Presidente Prudente, SP

BRAZIL

Email: suelinic@hotmail.com

Received: 21-01-2009

Accepted: 26-06-2009 